\title{
Harm to patients and others caused by impaired junior doctors compelled to work 30-hour shifts or longer: Can the minister of health, provincial MECs for health and public health officials be held liable?
}

\author{
D McQuoid-Mason, BComm, LLB, LLM ,PhD \\ Centre for Socio-Legal Studies, University of KwaZulu-Natal, Durban, South Africa
}

Corresponding author: D McQuoid-Mason (mcquoidm@ukzn.ac.za)

Junior doctors in most provinces in South Africa are compelled to work 30-hour shifts without a break. Shifts in excess of 24 hours can result in serious bodily harm to patients, third parties and the doctors themselves. These risks have been drawn to the attention of the health authorities but the 30-hour policy continues to be implemented in all provinces, except recently in the Western Cape.

Public health officials may be held directly liable for the harm caused to patients, third parties or the junior doctors themselves, if it can be shown that they are at fault and are acting unlawfully in violation of the Constitution. Where officials carry out the unlawful orders of senior officials, including the minister of health and provincial members of the executive council (MECs) for health, they may not raise the defence of 'obedience to orders' and may be held directly liable for harm caused. Superior officials issuing such orders will also be held directly liable for harm caused.

S Afr J Bioethics Law 2016;9(1):52-56. DOI:10.7196/SAJBL.495

It is alleged that junior doctors were subjected to 'forced labour' and 'slave labour' by being compelled to work 30-hour shifts and its dangers were identified. ${ }^{[1]}$ The warnings and recommendations seem to have been ignored by the health authorities, except in the Western Cape where shifts have been reduced to 24 hours. ${ }^{[2]}$ The fiancé of a woman who died as a result of a motor accident caused by a medical intern (who also died), who was tired because of working 'extraordinarily long hours', was going to sue the Department of Health for her death. The Department of Health responded that it is 'thinking of reviewing the policy.[3]

Can the minister of health, provincial members of the executive council (MECs) responsible for health, or other public health officials be held directly liable for harm to patients, third parties or the junior doctors themselves, caused by impairment of junior doctors being compelled to work 30-hour shifts? Direct liability differs from vicarious liability as such officials can be sued personally, ${ }_{1}^{[4]}$ and can be criminally charged or disciplined by the Health Professions Council of South Africa (HPCSA). In a civil claim they may also be subjected to vicarious liability in their representative capacity. Civil liability can be imposed, irrespective of fault on their part, where they are the employers, provided the junior doctors acted in the course and scope of their employment. ${ }^{[5]}$ However, they cannot be charged personally with a crime or disciplined by the HPCSA if they were not at fault.

To decide whether public health administrators can be held directly liable for harm to patients, third parties and the junior doctors themselves, the following must be considered:

\section{Do 30-hour shifts cause impairment?}

The HPCSA Handbook on Internship Training states that medical interns should not work continuously for more than 30 hours, ${ }^{[6]}$ similar to the original limit of the US Accreditation Council for Graduate Medical Education (ACGME), which was widely criticised for putting medical interns and patients at risk of harm. ${ }^{[7]}$

Studies on sleep deprivation and impaired performance by medical interns in the US show that:

- after 24 hours of continuous wakefulness impairments in performance are similar to those induced by a blood alcohol level of $0.10 \%{ }^{[8]}$

- medical interns working 24-hour shifts made $36 \%$ more serious medical errors and $460 \%$ more diagnostic errors than those working 16 -hour or shorter shifts ${ }^{[9]}$

- those working 24 -hour shifts also had a $61 \%$ chance of needlestick and other sharps injuries ${ }^{[10]}$

- and the chances doubled of those working 24-hour shifts being involved in motor collisions on the way home from work. ${ }^{[1]}$

The ACGME requirements have been amended so that the duty period of first-year medical interns does not exceed 16 hours and for other interns does not exceed 24 hours. ${ }^{[12]}$ The dangers to medical interns and patients of the South African (SA) rule based on the criticisms of the earlier 30-hour ACGME requirements in the US have been drawn to the attention of the HPCSA, provincial MECs for health and the minister of health by petitions from junior doctors. They requested that there should be 'an immediate 24-hour cap to all shifts with further review and reduction to 16 hours in future. ${ }^{[13]}$

\section{Can junior doctors be compelled to work 30-hour shifts?}

Junior doctors undertaking community service lack bargaining power because they are compelled to work 30-hour shifts, failing which 
they cannot qualify to practise medicine in SA. ${ }^{[1]}$ They must work up to 200 hours a month under the state's commuted overtime policy and 'overtime over 80 hours is unpaid!'[1] Such practices violate the SA Constitution, ${ }^{[14]}$ which guarantees everyone, including junior doctors, the right to fair labour practices (section 23(1)) and freedom from forced labour (section 13). ${ }^{[1]}$

The HPCSA rules make it unethical for doctors 'to be exploited in any manner, ${ }^{\prime 115]}$ and should a medical intern become impaired and possibly harm their patients, the HPCSA requires them to report this to their employer and also to 'self-report' their condition to the HPCSA. ${ }^{[16]}$ The HPCSA defines impairment as: 'a mental or physical condition which affects the competence, attitude, judgment or performance of professional acts by a registered practitioner.[17] Employers should assist practitioners to alleviate their impairments so as not to threaten their own health, their patients or third parties, rather than to act punitively towards them. This approach is taken by the Health Committee of the HPCSA. ${ }^{[18]}$ However, despite the HPCSA enjoining doctors to 'self-report' impairment, the HPCSA Handbook on Internship Training condones such possible impairment by stating that medical interns should not work continuously for more than 30 hours. ${ }^{[6]}$ This policy has apparently been reviewed. ${ }^{[2]}$

In medical emergencies junior doctors may be required to work extralong hours because the Constitution states that nobody may be refused emergency medical treatment. ${ }^{[19]}$ However, medical interns cannot be regarded as working under emergency conditions continuously during their community service as this would amount to an unfair labour practice and forced labour in breach of the Constitution. ${ }^{[14]}$ Public health officials justifying the working of 30-hour shifts by junior doctors as a response to a 'permanent medical emergency' would be unlikely to succeed in a court of law.

For public health administrators to be held legally liable for harm caused to patients, third parties and junior doctors through making them work 30-hour shifts, it must be shown that they:

- were at fault

- acted unlawfully

- caused or contributed to the resulting harm

- caused damage to the persons concerned.

Where such administrators are state employees, the state may also be vicariously liable for their wrongful acts or omissions. ${ }^{[5]}$

\section{Are public health officials at fault when requiring interns to work 30 -hour shifts that may harm patients, third parties or the junior doctors themselves?}

Considerable scientific evidence has demonstrated the dangers to the patients of medical interns, third parties and the junior doctors themselves, when they are required to work 30-hour shifts. Therefore public health officials should know, or foresee, that interns who work such shifts are likely to become impaired and may cause harm. Damages that can be claimed for such harm depends upon whether the fault of the public health officials concerned arises from intention or negligence.

Intention may be 'actual' or 'eventual.' 'Actual intention' means that a person directs their will to cause the death of a particular person, knowing that their act is unlawful. ${ }^{[20]}$ 'Eventual intention' means a person subjectively foresees that their conduct or omission may cause the death or injury of another person and reconcile themselves with this possibility (dolus eventualis). ${ }^{[21]}$ Therefore if public health officials subjectively foresee that interns, who are required to work 30-hour shifts would become impaired and are likely to harm patients or others, and reconcile themselves to this possibility, in law they will have had the 'eventual intention' to cause such harm.

Negligence is concerned with the conduct of a person measured objectively against the standard of whether a reasonable person in the same situation would have foreseen the likelihood of harm and taken steps to guard against it. ${ }^{[22]}$ Therefore, if a reasonably competent public health official ought to have foreseen that medical interns working 30-hour shifts are likely to harm patients or others and could have taken steps to guard against such harm e.g. by applying a 16 - 18-hour shift limit, ${ }^{[9]}$ but fail to do so, they may be liable for negligence.

Where the dangers of medical interns harming their patients, third parties or themselves when working 30-hour shifts have been drawn to the attention of the minister of health, provincial MECs for health or hospital administrators, ${ }^{[13]}$ all of them may be found to have 'actual' or at least 'eventual' intention to harm patients by compelling impaired junior doctors to work long hours.

\section{Do administrators who require interns to work 30-hour shifts act unlawfully?}

Unlawfulness is an essential element for deciding whether a person is found guilty of a crime or civil wrong in situations where bodily harm or death has been caused to another person by their passive or active conduct. ${ }^{[23]}$ Before the Constitution was enacted, the common law test for unlawfulness was the 'legal convictions of the community'.[2]

The courts have held that the values of the Constitution, and not public opinion, should determine whether or not a person has acted unlawfully. ${ }^{[24]}$ Legislative provisions may also be evidence of unlawfulness where certain conduct is prescribed by legislation and the provisions in the relevant statute have been breached by somebody. ${ }^{[25]}$ Similarly, the ethical rules of the HPCSA may guide the courts in deciding whether the physician's conduct should be considered as wrongful, although these are not binding on the courts.

The Constitution ${ }^{[14]}$ is clear that everyone, including junior doctors, ${ }^{[1]}$ has 'the right to fair labour practices' (section 23(1)) and not to be subjected to 'forced labour' (section 13). Everyone also has 'the right to bodily and psychological integrity' (section 12(2)) which applies to patients, third parties and the junior doctors. Studies have indicated that the bodily and psychological integrity of intern doctors forced to work for uninterrupted periods of wakefulness of 24 hours or more have been violated because they have experienced considerable increases in subcutaneous and sharps injuries, ${ }^{[10]}$ and motor accidents when driving home after work, ${ }^{[11]}$ resulting in injuries to themselves and third parties. Requiring interns to work uninterrupted for 24 hours exponentially increases the risk of harm to patients by exposing them to diagnostic and serious medical errors. ${ }^{[9]}$ This is unlawful and violates the Constitutional rights of patients.

The National Health $\mathrm{Act}^{[26]}$ states that health establishments 'must implement measures to minimise ... injury or damage to the person or property ... of health personnel working at that establishment' (section 20(3)(a)). Compelling junior doctors to work for periods of 24 hours or longer could cause bodily and psychological injuries. Long hours may also cause damage to their property, e.g. where doctors have car accidents while driving home because they are not provided 
with transport from, or housed near, their health establishment. ${ }^{[1]}$ The failure to minimise such injury or damage to the person or property of intern doctors may be regarded as unlawful and a breach of the National Health Act.

\section{Has the conduct of healthcare} administrators, who require interns to work 30-hour shifts, caused the harm to patients or other persons?

Does the conduct of the minister of health, provincial MECs for health or hospital administrators, who require junior doctors to work for 30 hours 'cause' the injury or damage suffered by patients, third parties or the doctors themselves? 'Causation' refers to an act or omission that causes or accelerates the harm suffered by another person. ${ }^{[27]}$ Any person who contributes to the harm suffered by another is regarded as having caused that harm. ${ }^{[28]}$ Where more than one person contributes to the harm suffered by a person, each concerned may be regarded as a joint wrongdoer. ${ }^{[29]}$ Causation must be both 'factual' and 'legal' for an alleged wrongdoer to be held liable.

\section{'But for' test for factual causation}

The test for factual causation is 'but for' the wrongful act or omission of the person concerned, the injured person would not have suffered injury. ${ }^{[30]}$ For instance, can it be said that 'but for' the fact that a junior doctor had to work a 30-hour shift and was tired she would not have injured herself or a patient, or crashed her motor car injuring or killing others? If the answer is 'yes' the persons responsible for compelling the junior doctor to work such long hours have factually caused or contributed to the injuries and damage that resulted. If the factual causation test is affirmed, it must then be decided whether the alleged wrongdoers have legally caused the injuries or damage. The traditional tests are the 'foreseeability' and 'direct consequences' tests, although the courts have recently adopted a more comprehensive 'flexible' test.

\section{'Foreseeability' test for legal causation}

The foreseeability test requires the alleged wrongdoer to have reasonably foreseen the likelihood of the harm to the injured person. ${ }^{[30]}$ Should a reasonable person in the position of the alleged wrongdoer have foreseen the likelihood of harm and taken steps to avoid it? ? $^{[2]}$ The wrongdoer need only foresee the likelihood and general nature of the harm, and not its extent. ${ }^{[31,32]}$

When harm is caused to patients or third parties by junior doctors the test is whether a reasonable minister of health, MEC for health or other public health official should have foreseen the likelihood of such harm being caused when compelled by them to work 30-hour shifts, and whether they could have taken steps against the harm occurring. Because the minister of health, MECs for health and other public health officials had been warned about these dangers, ${ }^{[13]}$ they were, or ought to have been, aware of them and have foreseen their consequences. They were also advised that the dangerous consequences for patients, third parties and junior doctors could be reduced by limiting intern shifts to 24 hours, and eliminated by reducing shifts to 16 hours. ${ }^{[13]}$ Therefore, the conduct of the minister of health, the MECs for health and other public officials in failing to prevent the harmful consequences they were warned about, satisfies the foreseeability test for legal causation.

\section{'Direct consequences' test for legal causation}

The direct consequences test states that wrongdoers are liable for the consequences of their unlawful acts unless there was a 'new intervening act' (novus actus interveniens) between the wrongdoer's original act and the plaintiffs harm. ${ }^{[33]}$ The novus actus principle, however, cannot apply when the likelihood of harm to some other person is a 'risk inherent' in the conduct of the alleged wrongdoer. ${ }^{[33]}$

When applying the direct consequences test to harm caused by junior doctors to their patients, other persons and themselves, the injured persons must prove that the doctor's conduct at the time was a risk inherent in the situation and not a new intervening act. Medical interns who have been exposed to over 24 hours of wakefulness: have the same performance levels as a person under the influence of alcohol ${ }_{1}^{[8]}$ making them dangerous when dealing with patients and driving home; ${ }^{[10]}$ make considerably more serious medical errors and exponentially more diagnostic errors than those working 16-hour or shorter shifts, ${ }^{[9]}$ posing a danger to patients; and have a greatly increased chance of needlestick and other sharps injuries, ${ }^{[10]}$ thus endangering themselves. Harm to patients, third parties and junior doctors themselves is a risk inherent in the situation and a direct consequence of the minister of health, provincial MECs for health and other public health officials concerned compelling such doctors to work 30-hour shifts.

\section{'Flexible' test for legal causation}

The flexible test initially considered whether there is 'a sufficiently close connection' between the wrongdoer's conduct and its consequences, ${ }^{\left[{ }^{[3]}\right.}$ taking into account policy considerations and factors such as reasonableness, fairness and justice. ${ }^{[35]}$ Subsequently it was refined to be 'a flexible one in which factors such as reasonable foreseeability, directness, the absence or presence of a novus actus interveniens, legal policy, reasonability, fairness and justice all play their part. ${ }^{\prime[36]}$

When the flexible test is applied to junior doctors who are required to work 30-hour shifts, it is clear that the foreseeability and 'direct consequence' tests are satisfied. Furthermore, 'legal policy, reasonability, fairness and justice' demand that the minister of health, provincial MECs for health and other public health officials do not expose junior doctors to situations that violate their constitutional rights ${ }^{[14]}$ to bodily and psychological integrity (section 12(2)), fair labour practices, (section 23(1)) and freedom from forced labour (section 13), and the rights of patients and third parties to 'bodily and psychological integrity'.

\section{Is there contributory fault by junior doctors who continue working 30-hour shifts when knowing that they are impaired?}

Contributory fault arises where persons suing others have contributed to the harm suffered by them through their own negligent or intentional conduct. ${ }^{[36]}$ Junior doctors have limited bargaining power regarding compulsory community service. However, community service does not exempt them from the ethical rules of their profession and their legal responsibilities towards their patients. Despite the anomalous condoning of 30-hour shifts by the HPCSA Handbook on Internship Training, ${ }^{[6]}$ the rules of the HPCSA require doctors not to allow themselves 'to be exploited in any manner ${ }^{\prime[15]}$ and to 'self-report' 
any impairments that may prevent them carrying out their duties in a professional manner. ${ }^{[15]}$ The rules must be followed as they carry more weight than the Handbook, which is merely a guide.

Where junior doctors feel that they are exhausted and impaired because of long working hours they should report this to their line managers and request to be relieved of their duties. However, such doctors often may 'have no awareness of their limitations.'[37] Medical emergencies may require them to assist as nobody may be refused emergency medical treatment in terms of the Constitution ${ }^{[14]}$ (section 27(3)). In non-emergencies where line managers threaten medical interns with disciplinary action if they leave, they should inform them that they must report their impairment and their compulsion to work despite this to the HPCSA. ${ }^{[16]}$ Line managers who are registered with the HPCSA may be disciplined for unprofessional conduct by causing junior doctors to continue working long hours in non-emergency situations while they are impaired, and exposing patients, third parties and the doctors themselves to harm.

Except in emergencies, junior doctors who work long hours, knowing that they are impaired and do not inform their line managers, may be found guilty of contributory negligence. They could be cited as joint wrongdoers ${ }^{[29]}$ if patients or third parties are harmed as a result. If medical interns do not notify their line managers of their known impairment, their line managers would not be directly at fault but could be held vicariously liable for the wrongful acts of the junior doctors. ${ }^{[5]}$ Vicarious liability is imposed on employers irrespective of fault by them where their employees negligently or intentionally harm others while acting within the course and scope of their employment - even if it is against the employers' instructions. ${ }^{[5]}$

\section{Is the damage suffered by patients, third parties or junior doctors themselves, arising from 30-hour shifts prescribed by public health officials, actionable?}

Where someone intentionally harms another person, causing physical or psychological injury, that person may recover damages for pain and suffering ${ }_{1}^{[38]}$ loss of amenities of life ${ }^{[39]}$ and past monetary losses such as lost earnings, medical expenses, and prospective losses such as loss of future earning capacity and future medical expenses. ${ }^{[40]}$ If a breadwinner is killed, the dependents may claim for loss of support. ${ }^{[41]}$ Where the wrongdoer acted intentionally, the injured parties may also claim sentimental damages to obtain 'satisfaction' for violations of their personality rights such as their dignity, ${ }^{[42]}$ reputation ${ }^{[43]}$ or privacy. ${ }^{[4]}$

A person harmed physically or psychologically through negligence may claim damages for pain and suffering, loss of amenities of life, and past and prospective monetary losses, but not sentimental damages..$^{[45]}$ However, injured persons may recover for 'emotional shock' if they can show that they have suffered a psychiatric illness that requires treatment as a result of the harmful act, e.g. where a parent sees his or her child killed by a motor car ${ }^{[22]}$ or a 'live-in fiancée' witnesses an accident in which her fiancé was injured ${ }^{[46]}$ The courts have also awarded damages for emotional shock in 'hearsay' situations where the trauma arises from a report of a tragic event, e.g. a report of a death of a person's child. ${ }^{[4]}$ The test is whether the nature of the harm, viz. 'psychological harm', is reasonably foreseeable. ${ }^{[22]}$

Where junior doctors negligently injure or cause the deaths of patients or third parties or severely injure themselves because they have been compelled to work 30-hour shifts while impaired, the public health officials requiring them to do so will be liable to pay damages to the relevant parties. The nature of the damages, which the injured parties may claim, depends on whether the officials acted intentionally or negligently.

Can the defence of "obedience to orders" be raised by public health administrators who are directed by the minister of health or provincial MECs for health to compel junior doctors to work 30-hour shifts, and can such a defence be relied on by junior doctors who work in such shifts?

State officials and employees are generally personally liable for wrongful acts committed by them and cannot rely on being ordered to carry out unlawful acts by their superiors. ${ }^{[48]}$ However, an exception could be when state officials or employees act under 'duress' which would justify 'the defence of necessity in the form of compulsion, ${ }^{\text {, }}{ }^{49]}$ because they are not acting from their own free will. The defence of necessity can be used when a person breaks the law to prevent death or serious bodily injury, e.g. operating on a person without consent in an emergency, ${ }^{[50]}$ but in criminal cases not out of 'economic necessity', e.g. where people fear loss of their employment. ${ }^{[51]}$

In civil cases, the situation is different where a person is threatened with the loss of their employment (which can be rectified by obtaining another job) and their professional licence. An unjustified threat to prevent a person from practising their chosen profession violates their right in the Constitution ${ }^{[14]}$ to 'choose their trade, occupation or profession freely'(section 22), and can also be regarded as 'duress'. Therefore, being forced to work under conditions resulting in the continuous threat of deprivation of the right to choose one's profession freely should qualify as 'necessity in the form of compulsion! ${ }^{[49]}$

However, public health officials who obey the unlawful orders of their superiors cannot rely on the defence of 'obedience to orders' if they carry them out because of fear of losing their livelihood by not complying ${ }^{[52]}$ An unlawful order would require such officials to compel junior doctors to work 30-hour shifts in non-emergencies which cause them to become impaired. In such situations, public health officials who implement orders from the minister of health or the provincial MECs for health to impose 30-hour shifts on junior doctors, which result in impairment cannot raise the defence of 'obedience to orders'. Superior officials who issue such orders will also be directly liable as joint wrongdoers. ${ }^{[29]}$

Junior doctors who know that they are impaired, ${ }^{[36]}$ and do not report this to their line managers or the HPCSA because of fear of losing the right to practice in $\mathrm{SA}$, can rely on the defence of 'obedience to orders' because they were subjected to duress. ${ }^{[49]}$

\section{References}

1. Erasmus N. Slaves of the state - medical internships and community service in South Africa. S Afr Med J 2012;102(8):655-658. http://dx.doi.org/10.7196/ SAMJ.5987

2. Junior doctors victory in Cape ups pressure on government. Cape Town: Medical Brief, 17 August 2016. http//www.medicalbrief.co.za/archives/junior-doctors-winfirst-victory-western-cape/ (accessed on 19 August 2016).

3. Phaliso S. Medical intern crash toll rises. The Mercury. 29 June 2016:5.

4. McQuoid-Mason D. Public health officials and MECs should be held liable for harm caused to patients through incompetence, indifference, maladministration or negligence regarding the availability of hospital equipment. S Afr Med J 2016, 106(7):681-683. http://dx.doi.org/10.7196/SAMJ.2016.v106i7.10722

5. Minister of Police v Rabie 1986 (1) SA 117 (A). 
6. Medical and Dental Professions Board, Health Professions Council of South Africa. Handbook on Internship Training. Guidelines for Interns, Accredited Facilities and Health Authorities [Brochure]. Pretoria: HPCSA, 2013.

7. Volpp K, Landigran CP. Building Physician Work Hour Regulations from First Principles and Best Evidence. (htpp://www.ncbi.nim.nih.gov/pmc/articles. PMC3994976/) (accessed on 7 July 2016).

8. Dawson D, Reid K. Fatigue, alcohol and performance impairment. Nature 1997; 388(6639):235. http://dx.doi.org/10.1038/40775

9. Landregan CP, Rothschild JM, Cronin JW, et al. Effect of reducing interns' work hours on serious medical errors in intensive care units. N Engl J Med 2004; 351(18):18381848. http://dx.doi.org/10.1056/NEJMoa041406

10. Ayas NT, Barger LK, Cade BE, et al. Extended work duration and risk of self-reported percutaneous injuries in interns. JAMA 2006; 296(9):1055-1062. http://dx.doi. org/10.1001/jama.296.9.1055

11. Barger LK, Cade BK, Ayas NT, et al. Extended work shifts and the risk of motor vehicle crashes among interns. N Engl J Med 2005;352(2):125-134. http://dx.doi. org/10.1056/NEJMoa041401

12. Accredited Council for Graduate Medical Education. Common Program Requirements paras VI.G.4.a) and VI.G.4.b). Chicago: ACGME, 2011. https://www. acgme.org/Portals/O/PDFs/Common_Program_Requirements07012011[2].pdf. (accessed on 7 July 2016).

13. Change.org, Inc. Van der Westhuizen HM. Call for safe working hours for junior doctors. California: Change.org, 2016. https://www.change.org/p/minister-ofhealth-south-africa-call-for-safe-working-hours-for-junior-doctors. (accessed on 7 July 2016).

14. South Africa. Constitution of the Republic of South Africa, 1996.

15. Health Professions Council of South Africa. Rule 22 of HPCSA. Ethical and Professional Rules of the HPCSA. Government Notice R717. Pretoria: Government Gazette No. 29079 of 4 August 2006. https://www.hpcsa.co.za/downloads/ethical rules/ethical_rules-of_conduct_2011.pdf. (accessed 7 July 2016).

16. Health Professions Council of South Africa. Rule 25(1)(b) of HPCSA. Ethical and Professional Rules of the HPCSA. Government Notice R717. Pretoria: Government Gazette No. 29079 of 4 August 2006. https://www.hpcsa.co.za/downloads/ethical_ rules/ethical_rules-of_conduct_2011.pdf. (accessed 7 July 2016).]

17. Health Professions Council of South Africa. Rule 1 of HPCSA. Ethical and Professional Rules of the HPCSA. Government Notice R717. Pretoria: Government Gazette No. 29079 of 4 August 2006. https://www.hpcsa.co.za/downloads/ethical_rules/ ethical_rules-of_conduct_2011.pdf. (accessed 7 July 2016).

18. Dhai A, Szabo CP, McQuoid-Mason DJ. The impaired practitioner - the scope of the problem and ethical challenges. S Afr Med J 2006;96(10):1069-1072.
19. South Africa. Constitution of the Republic of South Africa, Section 27(3) of 1996.

20. S v. Hartmann 1975 (3) SA 532 (C).

21. Cf. Burchell J. Principles of Criminal Law. 3rd ed. Lansdowne: Juta, 2006:461 463.

22. Bester v Commercial Union Versekeringsmpy van SA Bpk 1973 (1) SA 769 (A).

23. Cf. Clarke v Hurst NO 1992 (4) SA 630 (D).

24. S v Makwanyane 1995(3) SA 391 (CC).

25. Patz v Greene 1907 TS 427.

26. South Africa. National Health Act No. 61 of 2003.

27. Burchell J. Principles of Criminal Law. 3rd ed. Lansdowne: Juta, 2006:209.

28. Cf. S v Daniels and Others 1983 (3) SA 275 (A).

29. South Africa. Apportionment of Damages Act No. 34 of 1956, Sections 1(1) (a) and 2(13).

30. Minister of Police v Skosana 1977 (1) SA 31 (A).

31. Ocean Accident \& Guarantee Corp Ltd v Koch 1963 (4) SA 147 (A).

32. Kruger $v$ Van der Merwe 1966 (2) SA 266 (A).

33. Alston v Marine \& Trade Insurance Co Ltd 1964 (4) SA 112 (W)

34. Mukheiber v Raath 1999 (3) SA 1065 (SCA).

35. S v Mokgethi 1990 (1) SA 32 (A).

36. Smit v South British Insurance Co Ltd 1962 (3) SA 826 (A).

37. Morrison I, Flower D, Hurley J, MacFadyen RJ. Working night shift: A necessary time for training or a risk to health and safety? J R Coll Physicians Edinb 2013 43:230-235.

38. Standard Chartered Bank of Canada v Nedpenn Bank Ltd. 1994 (4) SA 747 (A)

39. Sandler v Wholesale Coal Suppliers Ltd 1941 AD 194.

40. Administrator-General, South West Africa v Kriel 1988 (3) SA 275 (A)

41. Guardian National Insurance Co Ltd v Van Gool 1992 (4) SA 61 (A).

42. Legal Insurance Co Ltd v Botes 1963 (1) SA 608 (A)

43. Mathews v Young 1922 AD 492.

44. Argus Printing and Publishing Co Ltd v Inkatha Freedom Party 1992 (3) SA 579 (A)

45. Kidson v SA Associated Newspapers Ltd 1957 (3) SA 461 (W).

46. Union Government v Warneke 1911 AD 657.

47. Road Accident Fund v Sauls 2002 (2) SA 55 (SCA).

48. Barnard v SANTAM Bpk 1999 (1) SA 202 (SCA).

49. McDonald v Khumalo 1927 EDL 293.

50. S v Banda 1990 (3) SA 466 (B)

51. Stoffberg v Elliot 1923 CPD 148

52. $R \vee$ Canestra 1951 (2) SA 317 (A). 